Journal of Applied Pharmaceutical Science Vol. 4 (10), pp. 044-046, October, 2014

Available online at http://www.japsonline.com

DOI: $10.7324 / \mathrm{JAPS} .2014 .401008$

ISSN 2231-3354 (cc)) BY-NC-SA

\title{
In vitro cytotoxic effect of Cleistanthus collinus extracts and fractions on mouse cell line
}

\author{
Thamburaj Suman ${ }^{1}$, Ramaraj Elangomathavan ${ }^{1}$, Soundherrajan Ilavenil ${ }^{2}$ and Samiraj Ramesh ${ }^{3}$ \\ ${ }^{1}$ Department of Biotechnology, PRIST University, Thanjavur, Tamilnadu, India. \\ ${ }^{2}$ Grass Land and Forages Science, Rural Development Administration, National Institute of Animal science, Seonnghwaneup, South Korea. \\ ${ }^{3}$ Department of Microbiology, PRIST University, Thanjavur, Tamilnadu, India.
}

\begin{tabular}{|c|c|}
\hline ARTICLE INFO & ABSTRACT \\
\hline Article history: & \multirow{7}{*}{$\begin{array}{l}\text { Aqueous, methanol and ethyl acetate crude extracts and fractions were prepared using Cleistanthus collinus } \\
\text { Roxb. dry leaf powder. All the extracts and fractions were subjected to in vitro cytotoxic analysis using mouse } \\
\text { 3T3- L1 pre-adipocytes cell line. Rate of cell proliferation was calculated to determine the anti-proliferative } \\
\text { activity. Aqueous, methanol and ethyl acetate extracts }(\geq 100 \mu \mathrm{g} / \mathrm{ml} \text { ) significantly control cell proliferation at } \\
48 \mathrm{hr} \text { incubation. However, fractions exhibited higher level of toxicity and affect cell growth even at } 50 \mu \mathrm{g} / \mathrm{ml} \\
\text { concentration within } 28 \mathrm{hr} \text { incubation. Fractions obtained from methanol extract showed cytotoxic effect about } \\
43-76 \% \text { at } 50-250 \mu \mathrm{g} / \mathrm{ml} \text { at } 48 \mathrm{hr} \text { incubation (Concentration necessary to inhibit cell growth at } 50 \% \text { is } \sim 75 \\
\mu \mathrm{g} / \mathrm{ml} \text { ). Followed by, ethyl acetate fraction exhibited } 23-59 \% \text { of anti-proliferative activity (Concentration } \\
\text { necessary to inhibit cell growth at } 50 \% \text { is } \sim 180 \mu \mathrm{g} / \mathrm{ml} \text { ). It may be concluded that promising fractions of } C \text {. } \\
\text { collinus with higher toxicity level could be exploited for pharmacological purposes. }\end{array}$} \\
\hline Received on: 20/08/2014 & \\
\hline Revised on: 09/09/2014 & \\
\hline Accepted on: 18/09/2014 & \\
\hline Available online: $30 / 10 / 2014$ & \\
\hline Key words: & \\
\hline $\begin{array}{l}\text { Cleistanthus, cytotoxic, } \\
\text { fractions, leaf extracts, } \\
\text { mouse cells. }\end{array}$ & \\
\hline
\end{tabular}

\section{INTRODUCTION}

It is obvious that many pharmacological research groups have focused into natural products as source of new drug with pharmacological potential; these drugs were mainly used to cure diseases and syndromes with less toxic in human and animals. Cleistanthus collinus a member of Euphorbiaceae family is harboring pharmacologically potential and interesting property (Maji et al., 2010; Suman et al., 2013: Arivoli et al., 2011). C. collinus were normally used as a source of dangerous poisons (suicidal and homicidal) in Southeast Asian countries. All parts of the plant are toxic to the human and veterinary animals and principal toxins extracted from various parts of the plants are lignan lactones, diphyllin and glycosides such as Cleistanthin A and B (Eswarappa et al., 2000; Annapoorani et al., 1984). C. collinus leaves contain saponin, tannin and oduvin and the poisonous effect is attributed to oduvin usually occurs after drinking the decoction of the leaves of $C$. collinus leading

\footnotetext{
* Corresponding Author

Dr. R. Elangomathavan, Assistant professor, Department of Biotechnology, PRIST University, Thanjavur, Tamilnadu, India E-mail: relangomathavan@gmail.com ,Phone: 9884289207
}

to death within 1-3 days. Main clinical features of poisoning with C. collinus are hypokalemia, acidosis, hypotension and respiratory failure (Thomas et al., 1991; Subrahmanyam et al., 2003; Nandakumar et al., 1989). Perusal of the literature revealed that most of the works have been done on effect of the $C$. collinus extract on controlling the cancer cells either in vitro or in vivo level. The present study was carried out to investigate the effect or response of the normal cell line to the $C$. collinus extract and selected fraction.

\section{MATERIALS AND METHODS}

\section{Plant collection, extraction and fractionation}

The $C$. collinus plant leaves were collected from Virallimalai, Tamilnadu, India. The plant leaves were shade dried at room temperature and powdered to precede extraction. $2000 \mathrm{~g}$ of plant sample was subjected to the hot crude extract preparation using soxhlet apparatus. Distilled aqueous, methanol and ethyl acetate (Merck, Germany)) were used as solvents, crude extracts were concentrated and used for further analysis. Both methanol and ethyl acetate were subjected to column chromatography using silica gel (230-400 mesh, Merck, Germany) 
and eluted various fractions with chloroform, methanol, toluene and ethyl acetate as mobile phase. Fractions were subjected to develop TLC (Silica gel 60 F254 (Merck, Germany). Selected spot on the TLC plates were scrubbed and separated partially purified botanicals.

\section{Cytotoxicity assay}

The cytotoxicity assay was performed for extracts and fractions using EZ-CYTOX Cell Viability Assay Kit (ITSBIO, Korea). The water soluble tetrazolium [WST; 2(2-Methoxy-4nitrophenyl) - 3(4-Nitrophenyl)-5-(2, 4- disulfophenyl)-2-Htetrazolium monosodium] salt was used for analysis of the cell proliferation. Mouse 3T3- L1 pre-adipocytes cells were seeded in the 96 well at a density of $1 \times 10^{5}$ cells/ well. The cells were treated with different concentrations (100-500 $\mu \mathrm{g}$ for methanol and ethyl acetate extracts, $50-250 \mu \mathrm{g} / \mathrm{ml}$ for each fraction) of extracts and fractions. One well was kept as control without any addition of extracts and fractions. The setup was incubated at the $37^{\circ} \mathrm{C}$ in $5 \%$ $\mathrm{CO}_{2}$ incubator for $24 \mathrm{hr}$ and $48 \mathrm{hr}$ and then the culture was treated with WST reagent and incubated for 2 to $4 \mathrm{hr}$. The living cells absorbed the WST then it was converted into an orange color product. The intensity of colour was measured at $450 \mathrm{~nm}$ using spectra count ELISA reader and ratio of inhibition of proliferation was calculated.

\section{RESULTS}

Aqueous, methanol and ethyl acetate solvent based $C$. collinus leaf extracts were prepared and further fractionated the methanol extract with chloroform: methanol (4:1 ratio) solvents to get $27 \mathrm{mg}$ (dry weight) of residue. Similarly $175 \mathrm{mg}$ of residue as fraction was also obtained from ethyl acetate extract when using toluene: ethyl acetate (3:2 ratio) as eluent. Methanol fraction was yellow in color, partially soluble in methanol but highly soluble in chloroform. Final residue obtained after complete evaporation of methanol was amorphous in nature and yellow in colour. TLC analysis of the fractionated compound revealed that the single spot obtained with $\mathrm{Rf}$ value 0.55 in chloroform: methanol (1:1 ratio) as mobile phase. Second fraction that is ethyl acetate fraction was crystal in nature and dark green in color, soluble in all organic solvents. The Rf value of this spot is 0.37 in toluene:ethyl acetate ( $4: 1$ ratio) as mobile phase. In this present study, crude extracts as well as partially purified fractions were subjected to determine the antiproliferation property. Cell proliferation of 3T3- L1 pre-adipocytes cells was moderately affected when incubated along with crude extracts (50 - 250 $\mu \mathrm{g} / \mathrm{ml}$ ) rather than the acute impact observed when incubated along with the partially purified fractions $(50-250 \mu \mathrm{g} / \mathrm{ml})$ (Table $1 \& 2$ ). Compared with control the antiproliferation activity was propositionally increased along with the augment of toxicant concentration. From this study it is obvious that higher concentration of toxicants destroy the cells within short time of incubation, however, lower concentration also effective in controlling the growth of the cells provided the extension of the incubation period. All the three $C$. collinus leaf extracts (each 250 $\mu \mathrm{g} / \mathrm{ml}$ ) namely aqueous, ethyl acetate and methanol exhibited 37 , 44 and $38 \%$ of antiproliferative activity at $48 \mathrm{hr}$ incubation respectively as compared with control. However, partially purified fractions that are ethyl acetate and methanol fractions (each 250 $\mu \mathrm{g} / \mathrm{ml}$ ) significantly affect the cell proliferation and it could be represented as 59 and $76 \%$ of antiproliferative activity at $48 \mathrm{hr}$ incubation with normal 3T3- L1 pre-adipocytes cells. Concentration of toxicant necessary to inhibit cell growth at $50 \%$ level was also calculated for three kinds of extracts and two partially purified fractions. All the five test materials showed significant variations in the antiproliferative effect between the short $(28 \mathrm{hr})$ and long $(48 \mathrm{hr})$ time incubation periods. Of the three extracts, ethyl acetate extract exhibited the lowest $\mathrm{GI}_{50}$ at $48 \mathrm{hr}$ incubations than methanol and aqueous extracts which are having almost similar $\mathrm{GI}_{50}$ (Table 1). However, in the case of the fractions, methanol solvent derived one was highly effective $\left(\mathrm{GI}_{50}\right.$ $75 \mu \mathrm{g} / \mathrm{ml}$ ) in ceasing the cell growth rather than ethyl acetate solvent derived fraction $\left(\mathrm{GI}_{50} 180 \mu \mathrm{g} / \mathrm{ml}\right)$ (Table 2).

Table 1: Anti-proliferative effect of various crude extracts of C. collinus on mouse 3T3- L1 pre-adipocytes normal cell line

\begin{tabular}{|c|c|c|c|c|c|c|}
\hline \multirow{3}{*}{$\begin{array}{l}\text { Toxicant } \\
\text { Conc. } \\
(\mu \mathrm{g} / \mathrm{ml})\end{array}$} & \multicolumn{6}{|c|}{ Anti-Proliferative Activity $(\%) \pm$ S.D $*$} \\
\hline & \multirow{2}{*}{\begin{tabular}{|l} 
Aqueous \\
$28 \mathrm{hr}$ \\
\end{tabular}} & extract & \multicolumn{2}{|c|}{$\begin{array}{c}\text { Ethyl acetate } \\
\text { extract }\end{array}$} & \multicolumn{2}{|c|}{ Methanol extract } \\
\hline & & $48 \mathrm{hr}$ & $28 \mathrm{hr}$ & $48 \mathrm{hr}$ & $28 \mathrm{hr}$ & $48 \mathrm{hr}$ \\
\hline Control & $0 \pm 0$ & $0 \pm 0$ & $0 \pm 0$ & $0 \pm 0$ & $0 \pm 0$ & $0 \pm 0$ \\
\hline 50 & $12 \pm 1.2$ & $14 \pm 1.5$ & $8 \pm 1.1$ & $19 \pm 0.9$ & $14 \pm 0.8$ & $16 \pm 1.0$ \\
\hline 100 & $16 \pm 2.3$ & $22 \pm 2.1$ & $13 \pm 2.1$ & $25 \pm 1.4$ & $19 \pm 1.6$ & $22 \pm 1.3$ \\
\hline 150 & $19 \pm 2.8$ & $26 \pm 1.3$ & $16 \pm 0.8$ & $31 \pm 1.7$ & $23 \pm 1.4$ & $27 \pm 0.9$ \\
\hline 200 & $23 \pm 1.5$ & $33 \pm 1.2$ & $20 \pm 1.3$ & $33 \pm 1.5$ & $28 \pm 1.1$ & $33 \pm 1.5$ \\
\hline 250 & $27 \pm 1.7$ & $37 \pm 1.6$ & $23 \pm 0.7$ & $44 \pm 1.8$ & $32 \pm 1.7$ & $38 \pm 2.0$ \\
\hline$* * \mathrm{GI}_{50}$ & 470 & 325 & 550 & 290 & 390 & 320 \\
\hline
\end{tabular}
at $50 \%$.

Table 2: Anti-proliferative effect of various fractions of $C$. collinus on mouse 3T3- L1 pre-adipocytes normal cell line

\begin{tabular}{|c|c|c|c|c|}
\hline \multirow{3}{*}{$\begin{array}{c}\text { Toxicant } \\
\text { Conc. } \\
\text { ( } \mu \mathrm{g} / \mathrm{ml})\end{array}$} & \multicolumn{4}{|c|}{ Anti-Proliferative Activity (\%) \pm SD $*$} \\
\hline & \multicolumn{2}{|c|}{ Ethyl acetate fraction } & \multicolumn{2}{|c|}{ Methanol fraction } \\
\hline & $28 \mathrm{hr}$ & $48 \mathrm{hr}$ & $28 \mathrm{hr}$ & $48 \mathrm{hr}$ \\
\hline Control & $0 \pm 0$ & $0 \pm 0$ & $0 \pm 0$ & $0 \pm 0$ \\
\hline 50 & $2 \pm 0.6$ & $23 \pm 1.8$ & $35 \pm 1.6$ & $43 \pm 1.8$ \\
\hline 100 & $4 \pm 0.8$ & $32 \pm 2.1$ & $42 \pm 2.0$ & $60 \pm 2.3$ \\
\hline 150 & $9 \pm 1.4$ & $39 \pm 2.0$ & $47 \pm 2.1$ & $69 \pm 2.7$ \\
\hline 200 & $27 \pm 2.3$ & $56 \pm 1.7$ & $48 \pm 1.6$ & $70 \pm 1.8$ \\
\hline 250 & $41 \pm 2.6$ & $59 \pm 2.2$ & $58 \pm 2.3$ & $76 \pm 2.4$ \\
\hline$* * \mathrm{GI}_{50}$ & 350 & 180 & 210 & 75 \\
\hline
\end{tabular}

\section{DISCUSSION}

Cleistanthus collinus (Euphorbiaceae) is a naturally distributed in the dry forests of the southern and central parts of India. Many parts of the plants were reported as toxic however it has been exploited as drug since it harbours many valuable pharmacological properties. Many researchers have paid attention to this plant for isolating new phytochemical molecule for developing drugs against human cause (Govindachari et al., 1969; Ramar et al., 2014; Nagarajan et al., 2014). The present study has 
brought out some important observations in the context of toxic effect of $C$. collinus. Here the aqueous, methanol and ethyl acetate extracts from plant leaf showed higher level of toxicity at lowest concentration. Likewise the alcoholic extract of the whole plant of C. collinus was tested for anticancer activity in human epidermoid carcinoma of nasopharynx in culture, Walker carcinoma sarcoma 256 in rats and L-1210 lymphoid leukaemia in mice. The extract showed significant anticancer activity against human epidermoid carcinoma of the nasopharynx. The aqueous extract of $C$. collinus showed the cytotoxicity level at $10 \mu \mathrm{g} / \mathrm{ml}$ concentration in $28 \mathrm{hr}$ incubation itself (Bhakuni et al., 1969). It is further confirmed that C. collinus extracts and fractions have shown cytotoxicity effect on normal cell line of mouse (Pinho et al., 2007; Lakshmi et al., 1970). Similarly, the percent survival values of Chinese hamster ovary $\mathrm{CHO}$ cells, cervical carcinoma ( $\mathrm{Si} \mathrm{Ha)} \mathrm{cells} \mathrm{and} \mathrm{p53}$ deficient cell line K562 treated with 20 , 40, 60 and $80 \mathrm{mg} / \mathrm{ml}$ of Cleistanthin A were $78 \%, 52 \%, 30 \%$ and $12 \%$ respectively. The results indicated a progressive decrease in the survival of cells in response to increasing doses of Cleistanthin $\mathrm{A}$. The $\mathrm{IC}_{50}$ value of Cleistanthin A ranged from $0.4 \times 10^{-6}$ to $0.9 \times 10^{-6} \mathrm{M}$. Higher concentrations and long exposure to Cleistanthin A stimulate DNA strand breaks and apoptosis in Chinese hamster ovary $(\mathrm{CHO})$ cells, in cervical carcinoma ( $\mathrm{Si} \mathrm{Ha}$ ) cells and in a p53 deficient cell line K562 (Pradheep Kumar et al., 2000). In-vitro studies carried out by Pradheep Kumar et al., (1996) revealed that Cleistanthin B, isolated from the poisonous plant $C$. collinus showed potent anticancer properties in normal and tumor cells. Cleistanthin B exhibited $50 \%$ growth inhibition $\left(\mathrm{GI}_{50}\right)$ to normal cell lines at 2 $\times 10^{-5}$ to $4.7 \times 10^{-4} \mathrm{M}$ and for tumor cells the values ranged from 1.6 $\times 10^{-6}$ to $4 \times 10^{-5} \mathrm{M}$.

\section{CONCLUSION}

The present study is a primary analysis of $C$. collinus extracts and its fractions to ensure the toxicity property against mouse 3T3- L1 pre-adipocytes cell proliferation. Cell type cytotoxic specificity has to be done further for those promising fractions. In general, these results indicates that there was a significant antiproliferative effect even to the normal mouse cell line. As per the traditional knowledge, the plant $C$. collinus is used up for the antitumor treatment, so, cautions has to be taken to optimize the method of fractionation of the promising compounds having anticancer property and also fixing the effective concentration of the impure or pure phyto-compounds when used as drug. Moreover, fractions that have pronounced cytoxic activity should be evaluated further for the possible isolation and characterization of the phytocompounds and validation of the same to prove the specific biological properties.

\section{ACKNOWLEDGEMENT}

Author T. Suman is grateful to University Grand Commission, New Delhi for financial assistance as UGC-RGNF Research fellow.

\section{REFERENCES}

Annapoorani KS, Periakali P, Ilangovan S, Damodaran C, Sekharan PC. Spectrofluorometric determination of the toxic constituents of Cleistanthus collinus. J Anal Toxicol, 1984: 8: 182-6.

Arivoli S, Samuel T. Larvicidal efficacy of Cleistanthus collinus (Roxb.) (Euphorbiaceae) leaf extracts against vector mosquitoes (Diptera: Culicidae). Asi Pa J Trol Bio, 2011;1 (2): 281-283.

Bhakuni DS, Dhar ML, Dhar MM, Dhawan BN, Mehrota BN. Screening of Indian plants for biological activity part II. Indian Exp Bio, 1969; 7: 250-262.

Eswarappa S, Chakraborty AR, Palatty BU, Vasnik M. Cleistanthus collinus poisoning: Case reports and review of the literature. Clin Toxicol (Phila), 2000; 41: 369-72.

Govindachari TR, Sathe SS, Viswanathan N, Pai BR, Srinivasan M. Chemical constituents of Cleistanthus collinus (Roxb.) Tetrahedron, 1969; 25: 2815-2821.

Lakshmi TG, Srimannarayan G, Subbarao NV. A new glucoside from Cleistanthus collinus. Curr Sci, 1970; 39: 395-6.

Maji S, Dandapat P, Ojha D, Maity C, Halder SK, Das Mohapatra PK, Pathak TK, Pati BR, Samanta A, Mondal KC. In vitro antimicrobial potentialities of different solvent extracts of ethnomedicinal plants against clinically isolated human pathogens. J Phytology, 2010; 2(4); 57-64.

Nagarajan K, Soundarapandian K, Ramar R, Periyasamy S, Ramasamy T. Characterization, antioxidant and cytotoxicity evaluation of green synthesized silver nanoparticles using Cleistanthus collinus extract as surface modifier. Mater Res Bulletin, 2014; 49: 494-502.

Nandakumar NV, Pagala MKD, Venkataciiari SAT, Namba T, Grob D. Effect of Cleistanthus collinus leaf extract on neuromuscular function of the isolated mouse phrenic nerve-diaphragm. Toxicon, 1989; 27: 1219-1228.

Pinho PM, Kijjoa A. Chemical constituents of the plants of the genus Cleistanthus and their biological activity. Phytochem Rev, 2007; 6: 175-82.

Pradheep Kumar CP, Panneerselvam N, Rajesh S, Shanmugam G. Cytotoxic and genotoxic effects of Cleistanthin B in normal and tumour cells. Mutagenesis, 1996; 11: 543-547.

Pradheep Kumar CP, Panneerselvam N, Shanmugam G. Cleistanthin A causes DNA strand breaks and induces apoptosis in cultured cells. Muta Res, 2000; 464: 185-193.

Ramar G, Suman T, Elangomathavan R, Jeyasankar A. Larvicidal activity of biologically synthesised silver nanoparticles against dengue vector Aedes aegypti (Culicidae). Discovery, 2014; 9(23): 65-68.

Subrahmanyam DK, Mooney T, Raveendran R, Zachariah B. A clinical and laboratory profile of Cleistanthus collinus poisoning. J Assoc Physi India, 2003; 51: 1052- 4.

Suman T, Elangomathavan R. Bio-prospecting of Cleistanthus collinus and its antibacterial activity. Asi J Pharm Cli Res, 2013; 6(4): 206-209.

Thomas K, Dayal AK, Narasimhan Alka G, Seshadri MS, Cherian AM. et al. Metabolic and cardiac effects of Cleistanthus collinus poisoning. J Assoc Physi India, 1991; 39: 312-4.

How to cite this article:

Thamburaj Suman, Ramaraj Elangomathavan, Soundherrajan Ilavenil and Samiraj Ramesh. In vitro cytotoxic effect of Cleistanthus collinus extracts and fractions on mouse cell line. J App Pharm Sci, 2014; 4 (10): 044-046. 